\section{Neutral Sugar Analysis of Tobacco Cell Wall Fractions*}

\author{
by William S. Ryan, Jr.
}

Pbilip Morris Research Center, Richmond, Virginia, U.S.A.

\section{SUMMARY}

A method for the determination of the neutral sugar content of tobacco cell wall fractions has been developed. The seven neutral sugars - rhamnose, fucose, arabinose, xylose, mannose, glucose and galactose determined in the analysis represent the usual glycosyl residues found in plant cell wall polysaccharides.

In this procedure, the structural polysaccharides are acid hydrolyzed into their constituent monosaccharides. The monosaccharides are then reduced with sodium borohydride to the corresponding alditols. The alditols are converted to the acetates with acetic anhydride. The alditol acetates are quantitatively measured by capillary gas chromatography with flame ionization detection.

Both $72 \% \mathrm{H}_{2} \mathrm{SO}_{4}$ and $2 \mathrm{~N}$ trifluoroacetic acid have been used for acid hydrolysis of polysaccharides. Using model compounds, it was found that more complete recovery of the neutral sugars was obtained when the polysaccharide was hydrolyzed with $72 \% \quad \mathrm{H}_{2} \mathrm{SO}_{4}$. When the Bright tobacco insoluble fraction was hydrolyzed under these conditions, an $\mathrm{H}_{2} \mathrm{SO}_{4}$-insoluble residue remained.

The neutral sugar method was applied to fractions isolated from Bright tobacco. The results of the analysis provided a measure of the homogeneity of the cell wall fractions and thus helped indicate whether different types of structural polysaccharides were effectively separated from each other.

\footnotetext{
- Presented at the Coresta Symposium held in Winston-Salem, North Caroline, in November 1982.

Received: 17 th January 1983 - accepted: 9th November 1983.
}

\section{ZUSAMMENFASSUNG}

Zur Bestimmung der in den Zellwandfraktionen der Tabakpflanze enthaltenen neutralen Zucker wurde eine neue Methode entwickeit. Die sieben neutralen Zucker - Rhamnose, Fucose, Arabinose, Xylose, Mannose, Glucose und Galaktose -, deren Konzentrationen sich mit diesem Verfahren bestimmen lassen, sind die gewöhnlich in den Polysacchariden der Zellwand von Pflanzen vorkommenden Zuckerbestandreile.

Das Verfahren besteht aus folgenden Analyseschritten: Die als Gerüststoffe dienenden Polysaccharide werden durch saure Hydrolyse in ihre Monosaccharide überführt, die ihrerseits mittels Natriumborhydrid zu den entsprechenden Alditolen reduziert werden. Die Alditole werden mit Essigsäureanhydrid in Acetate umgewandelt. Die quantitative Bestimmung der Alditolacetate erfolgt kapillargaschromatographisch mit einem Flammenionisationsdetektor.

Die saure Hydrolyse der Polysaccharide wurde sowohl mit 72\%iger Schwefelsāure als auch mit $2 \mathrm{~N}$ Trifluoressigsäure durchgeführt. Mit Modellsubstanzen ergab sich für die neutralen Zucker eine höhere Wiederauffindungsrate, wenn mit $72 \%$ iger Schwefelsăure hydrolysiert wurde. Bei der Hydrolyse der unlöslichen Fraktion von Bright-Tabak fiel ein in Schwefelsäure unlöslicher Rückstand an.

Das beschriebene Verfahren wurde auf Zellwandfraktionen von Bright-Tabak angewandt. Die Ergebnisse geben Hinweise über die Homogenitāt der Zellwandfraktionen und zeigen an, inwieweit die verschiedenen Strukturpolysaccharide vollständig voneinander getrennt worden sind. 


\section{RÉSUME}

Une méthode a été mise au point en vue de la détermination de la teneur en sucre neutre des fractions de membranes cellulaires des plantes de tabac. Les 7 sucres neutres: rhamnose, fucose, arabinose, xylose, mannose, glucose et galactose, dont les concentrations sont déterminées à l'aide de cette méthode, sont les composants sucrés que l'on trouve habituellement dans les polysaccharides de la membrane cellulaire des plantes.

Les étapes de l'analyse sont les suivantes: les polysaccharides constituant la structure, subissent une hydrolyse acide afin d'être réduits en leur mono-saccharides, ces derniers étant alors réduits en les alditols correspondants au moyen de borohydrures de sodium. Les alditols sont alors convertis en acétates en faisant intervenir de l'anhydride acétique. $\mathrm{La}$ détermination quantitative des acétates d'alditol s'effectue par chromatographie gazeuse capillaire à l'aide d'un détecteur d'ionisation de flammes.

L'hydrolyse acide a été effectuée aussi bien avec de l'acide sulfurique à $72 \%$ qu'avec de l'acide trifluoracétique 2 N. En utilisant des substances types il est apparu que l'on obtenait un taux de récupération plus élevé des sucres neutres, lorsque l'hydrolyse se faisait à l'aide d'acide sulfurique à $72 \%$. Lors de l'hydrolyse de la fraction insoluble du tabac Bright, il subsiste un résidu insoluble dans l'acide sulfurique.

Le procédé décrit fut utilisé sur des fractions de membranes cellulaires de tabac Bright. Les résultats obtenus donnent une idée de l'homogénéité des fractions de membranes cellulaires et montrent dans quelle mesure les différents polysaccharides structurels ont été entièrement séparés les uns des autres.

\section{INTRODUCTION}

The cell walls of a plant consist of non-living material and provide the structural framework for the organism. It is the cell wall that determines the mechanical properties of the entire plant. Approximately ninety percent of the structural material of plant cell walls consists of polysaccharides (1). These cell wall polysaccharides are grouped into three classes: cellulose, the hemicelluloses and the pectic polysaccharides.

Studies on structural polysaccharides require a pure, homogeneous cell wall sample. This is accomplished by first removing non-structural constituents from the crude plant material. The purified wall preparation is then separated into the three polysaccharide fractions by preferential extraction and chromatography.

The next step in the elucidation of the structure of a cell wall polysaccharide is to determine the monosaccharide composition of the fraction. This analysis also provides a measure of the homogeneity of the polysaccharide fraction and thus the efficacy of the separation. The seven neutral sugars - rhamnose, fucose, arabinose, xylose, mannose, galactose and glucose - deter- mined in the analysis represent the usual glycosyl residues found in plant cell wall polysaccharides. The glycosyl residues are analyzed as their alditol acetates.

Neutral sugar analyses were necessary to the development of a general fractionation scheme for separation of the structural biopolymers of tobacco. In this paper, the results of the neutral sugar analysis of various tobacco cell wall fractions generated by the separation scheme are reported.

\section{EXPERIMENTAL}

\section{Materials}

The tobacco used for this work was a heavy, or bodied, flue-cured bright tobacco lamina from the upper midstalk position. This uncased tobacco was ground to pass through a 20 mesh screen prior to extraction.

\section{Fractionation of Tobacco}

The Bright tobacco lamina was fractionated by the method of Bokelman et al. (2) shown in Figure 1.

The Bright lamina was initially Soxhlet extracted for 18 hours with $80 \%$ aqueous ethanol to remove the soluble

Figure 1. Fractionation of Bright tobacco.

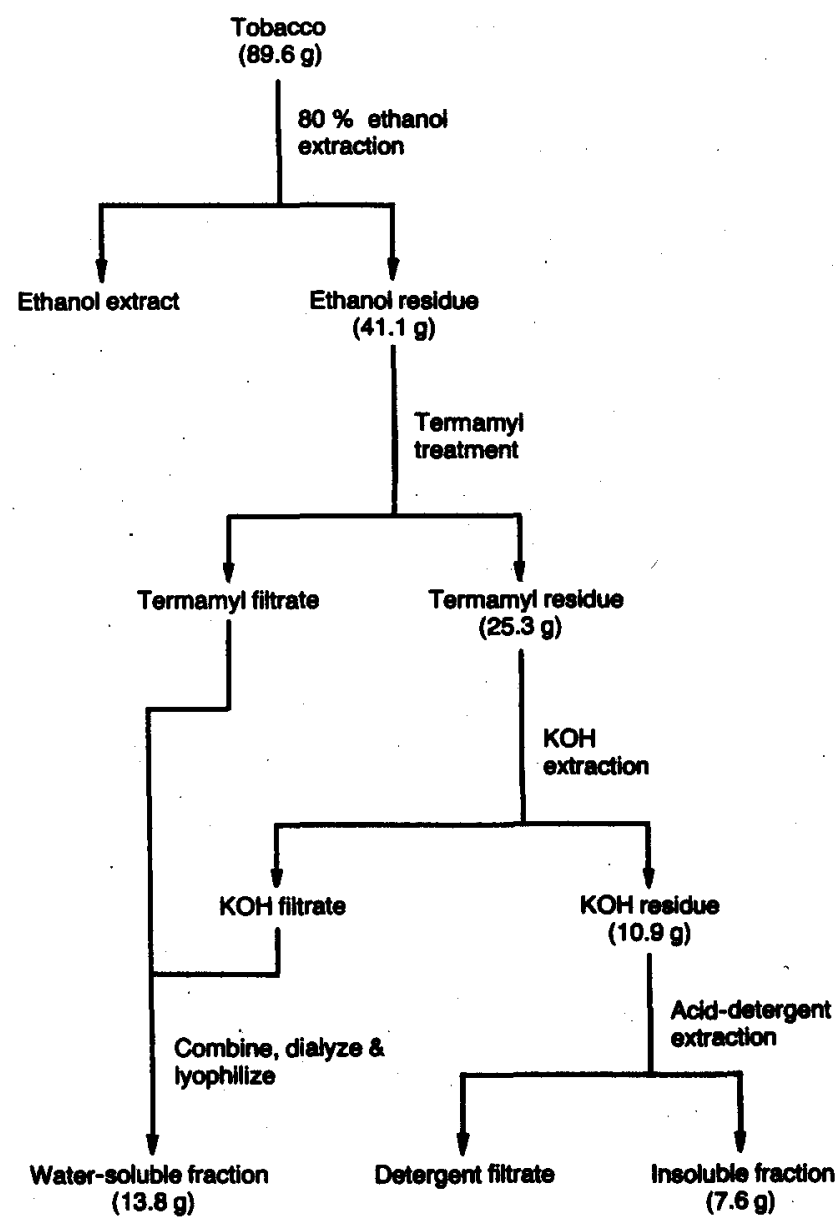


non-structural constituents. The ethanol extracted tobacco was then treated with Termamyl 60-L enzyme, a thermophilic amylase supplied by Novo Laboratories, Inc., to remove starch. The Termamyl ${ }^{\bullet}$ treated residue was then subjected to an alkaline extraction with $0.1 \mathrm{~N}$ $\mathrm{KOH}$. The alkaline extracted residue was then subjected to a detergent extraction with cetyltrimethylammonium bromide in $1.0 \mathrm{~N} \mathrm{H}_{2} \mathrm{SO}_{4}$. The material from this final extraction was termed the insoluble fraction. The aqueous filtrates from the Termamyl treatment and the alkaline extraction were combined, dialyzed with 12,000 molecular weight cut-off tubing and then lyophilized. The material obtained was termed the watersoluble fraction.

\section{Preparation of Alditol Acetate Derivatives}

The reactions involved in the preparation of alditol acetate derivatives for gas chromatographic analysis from the cell wall polysaccharides are shown in Figure 2.

The polysaccharide samples were hydrolyzed by either the sulfuric acid method of Theander and Aman (3) or the trifluoroacetic acid procedure described by Albersbeim et al. (4).

In the sulfuric acid procedure, a sample weighing 100 to $500 \mathrm{mg}$ was stirred at room temperature for two hours with $12 \mathrm{M} \mathrm{H}_{2} \mathrm{SO}_{4}$ in the ratio of $1.0 \mathrm{ml}$ of acid per $100 \mathrm{mg}$ of sample. The hydrolysis mixture was then diluted to $0.36 \mathrm{M} \mathrm{H}_{2} \mathrm{SO}_{4}$ by the addition of $32.5 \mathrm{ml}$ of $\mathrm{H}_{2} \mathrm{O}$ per $1.0 \mathrm{ml}$ of acid and refluxed for six hours. The solution was cooled to room temperature and filtered through a fritted glass büchner funnel (ASTM 40-60)

Figure 2. Conversion of polysaccharide to alditol acetates.
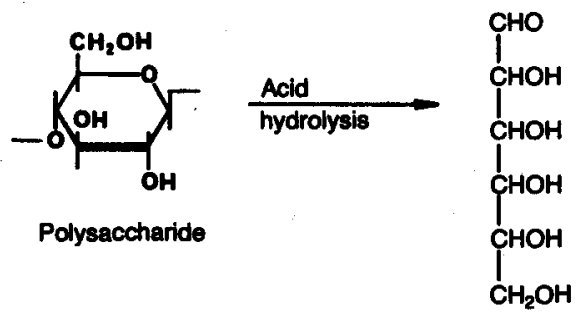

Aldose
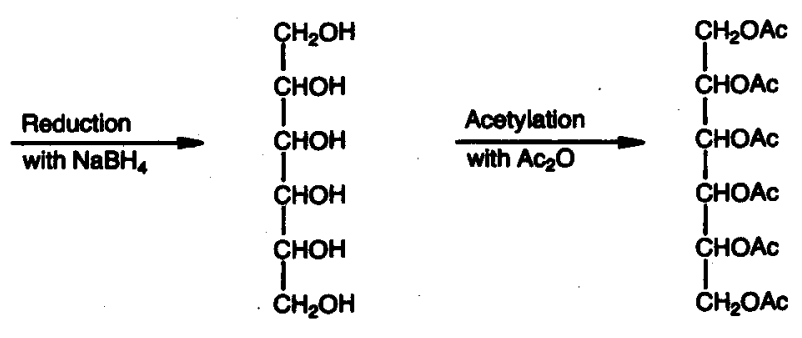

Alditol

Alditol acetate to remove insoluble material. A $25 \mathrm{ml}$ portion of the undiluted filtrate was treated with solid $\mathrm{BaCO}_{3}$ until gas evolution ceased and test paper indicated a $\mathrm{pH}$ of 6 to 7. The supernatant liquid was transferred to a test tube and centrifuged at 2500 r.p.m. for 10 minutes to remove any suspended material. A 150-200 $\mu$ l aliquot of the clarified solution was transferred to a Pyrex test tube with Teflon-lined screw cap and evaporated to dryness at $40^{\circ} \mathrm{C}$ under a stream of nitrogen on an analytical evaporator.

In the trifluoroacetic acid hydrolysis procedure, a 250 to $500 \mu \mathrm{Hg}$ sample was weighed into a Pyrex test tube with Teflon"-lined screw cap. Then $250 \mu$ lof aqueous 2.0 M trifluoroacetic acid were added and the mixture was heated at $120^{\circ} \mathrm{C}$ for 1.5 hours. After hydrolysis, the trifluoroacetic acid was removed by evaporation of the solution to dryness at $40^{\circ} \mathrm{C}$ under a stream of nitrogen on an analytical evaporator.

The aldoses in the dry residues were reduced to the corresponding alditols by the addition of $250-500 \mu \mathrm{l}$ of an aqueous $1.0 \mathrm{M}$ ammonia solution containing $10 \mathrm{mg} /$ $\mathrm{ml}$ of $\mathrm{NaBH}_{4}$. The reduction reaction proceeded at room temperature for one hour. Then, the excess borohydride was decomposed by the dropwise addition of glacial acetic acid until cessation of effervescence. Again, the solution was evaporated to dryness at $40^{\circ} \mathrm{C}$ in a stream of nitrogen. The borate produced by the decomposition of the borohydride was removed as the volatile trimethyl borate ester. First, the residue was treated with four $3 \mathrm{ml}$ portions of $10 \%$ acetic acid in methanol $(v / v)$ and blown to dryness with nitrogen after each addition. Then the residue was treated with four $3 \mathrm{ml}$ portions of methanol and blown dry with nitrogen after each addition.

Acetylation of the alditols was carried out by heating the residue with $100 \mu \mathrm{l}$ of acetic anhydride at $120^{\circ} \mathrm{C}$ for three hours. The sodium acetate remaining from the borate removal was a basic catalyst for this reaction. The acetylation mixture was diluted by the addition of $1 \mathrm{ml}$ of water. Next the excess acetic anhydride was hydrolyzed and neutralized by the addition of solid $\mathrm{Na}_{2} \mathrm{CO}_{3}$. The aqueous solution was then extracted with two successive $1 \mathrm{ml}$ aliquots of chloroform. The combined chloroform extracts were evaporated to dryness at $40^{\circ} \mathrm{C}$ with nitrogen on an analytical evaporator. The dry residue was stored at $5^{\circ} \mathrm{C}$ until analyzed by gas chromatography.

\section{Klason Residue}

In the sulfuric acid hydrolysis procedure, after the $0.36 \mathrm{M} \mathrm{H}_{2} \mathrm{SO}_{4}$ reflux solution had been filtered and the undiluted filtrate removed, any insoluble material remaining in the reflux flask was quantitatively transferred to the büchner funnel by washing with water. The büchner funnel was then dried in an oven at $105^{\circ} \mathrm{C}$ until constant weight was obtained. This insoluble material was termed the Klason residue (5). 


\section{Gas Cbromatography}

The samples were analyzed on a Hewlett-Packard 5880 A gas chromatograph equipped with a flame ionization detector and a $30 \mathrm{~m} \times 0.2 \mathrm{~mm}$ inside diameter fused silica capillary column coated with methyl silicone fluid. The injection port temperature was $240^{\circ} \mathrm{C}$, the detector temperature was $300^{\circ} \mathrm{C}$ and the oven temperature was programmed from $170^{\circ} \mathrm{C}$ to $200^{\circ} \mathrm{C}$ at $2 \%$ minute, then from $200^{\circ} \mathrm{C}$ to $240^{\circ} \mathrm{C}$ at $10 \%$ minute. The carrier gas, helium, was maintained at a pressure of $1.59 \times 10^{5} \mathrm{~Pa}$ and a flow rate of about $1 \mathrm{ml} /$ minute. Auxiliary helium, hydrogen and air flow rates to the above detector were $30 \mathrm{ml} /$ minute, $30 \mathrm{ml} /$ minute and $410 \mathrm{ml} /$ minute, respectively. A $1 \mu \mathrm{l}$ volume of the sample solution in 4-heptanone was injected with a split ratio of about 1/125.

Identification of the alditol acetates was based on the retention times of the individual compounds. Calibration curves for each of the individual sugars were generated by treating the pure compounds by both hydrolysis procedures. Myoinositol, added either with the $\mathrm{NaBH}_{4}$ reducing solution in the sulfuric acid method or with the acid solution in the trifluoroacetic acid procedure, served as an internal standard.

\section{RESULTS AND DISCUSSION}

A gas chromatogram of the alditol acetate derivatives of a standard neutral sugar mixture is shown in Figure 3. The retention times of the alditol acetates are listed in Table 1. All components have baseline separation, thus

Figure 3. Gas chromatogram of the aldhol acetate derivatives of a standard neutral sugar mixture.

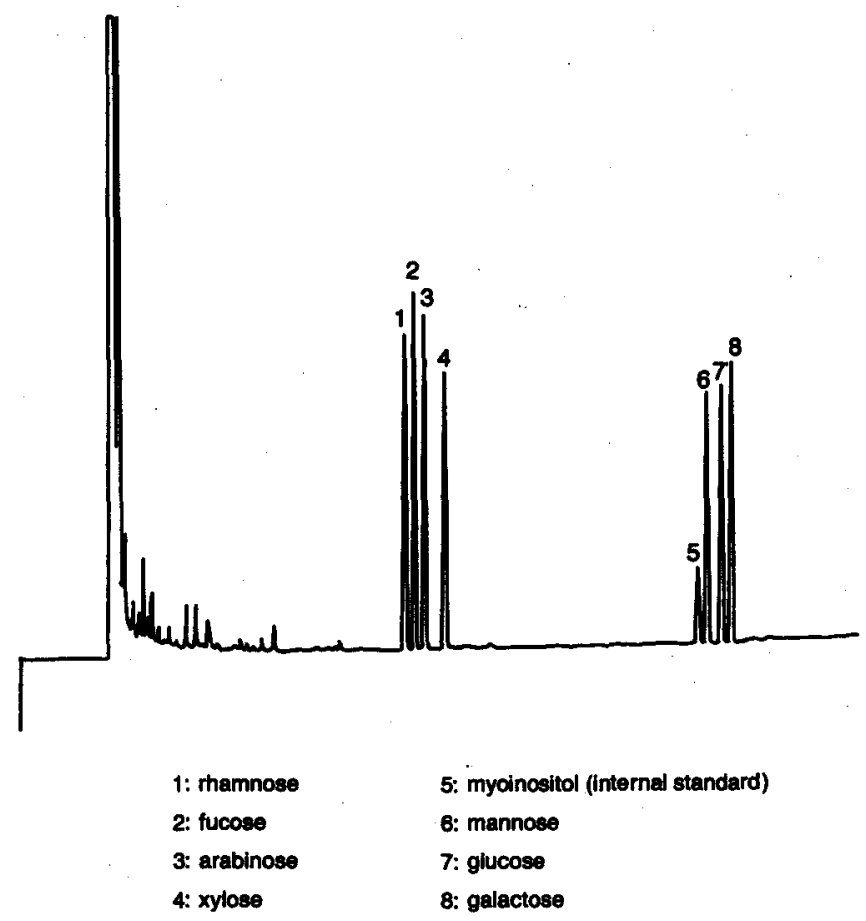

Table 2. Neutral sugar content of model compounds.

\begin{tabular}{|c|c|c|}
\hline Compound & $\begin{array}{l}\text { Hydrolysis } \\
\text { procedure }\end{array}$ & $\begin{array}{l}\text { Total neutral } \\
\text { sugars }(\%)^{*}\end{array}$ \\
\hline \multirow[t]{2}{*}{ Xylan } & Trifluoroacetic acid & $\begin{array}{l}78.2 \\
71.9\end{array}$ \\
\hline & $\mathrm{H}_{2} \mathrm{SO}_{4}$ & $\begin{array}{l}81.4 \\
88.6\end{array}$ \\
\hline \multirow[t]{2}{*}{ Cellulose } & Trifluoroacetic acid & $\begin{array}{l}19.7 \\
20.5\end{array}$ \\
\hline & $\mathrm{H}_{2} \mathrm{SO}_{4}$ & $\begin{array}{r}96.3 \\
100.3\end{array}$ \\
\hline
\end{tabular}

- Total neutral sugars $(\%)=\frac{\text { weight of total neutral sugars }}{\text { sample weight }} \times 100$

allowing complete qualitative and quantitative analysis of the neutral sugars as their alditol acetates. Osbima et al. (6) using a $50 \mathrm{~m} \times 0.2 \mathrm{~mm}$ inside diameter fused silica capillary column coated with SP-2100 methyl silicone fluid were unable to completely separate the alditol acetates of rhamnose, fucose and arabinose even with temperature programming.

Theander and Aman (3) used sulfuric acid hydrolysis for neutral sugar analysis of both the water-soluble and water-insoluble fractions of dietary fibers. However, Albersheim et al. (4) are ambiguous about the classes of polysaccharides that can be hydrolyzed by trifluoroacetic acid. The two hydrolysis procedures were therefore compared using model compounds. Larchwood xylan (Aldrich Chemical Co.) was used to represent a water-soluble polysaccharide and Sigmacell Type 100 cellulose (Sigma Chemical Co.) was chosen to represent an insoluble polysaccharide. The results of the comparison are shown in Tables 2 and 3.

The data for xylan demonstrate that while the neutral sugar distribution obtained from both procedures is equivalent, the sulfuric acid hydrolysis converts a larger fraction of the soluble polysaccharide to its monosaccharide constituents. The results obtained with cellulose indicate that trifluoroacetic acid is substantially less effective than sulfuric acid in hydrolyzing an insoluble polysaccharide. The neutral sugar distribution for cellulose contains xylose which indicates the cellulose is not pure but is probably contaminated with some hemicel-

Table 1. Retention times for alditol acetate derivatives of neutral sugars.

\begin{tabular}{l|c|c}
\hline Sugar & $\begin{array}{c}\text { Retention time } \\
(\min )\end{array}$ & $\begin{array}{c}\text { Relative } \\
\text { retention time }\end{array}$ \\
\hline L-Rhamnose & 8.75 & 0.569 \\
L-Fucose & 8.96 & 0.582 \\
L-Arabinose & 9.18 & 0.597 \\
D-Xylose & 9.64 & 0.626 \\
Myoinositol & 15.39 & 1.000 \\
D-Mannose & 15.59 & 1.013 \\
D-Glucose & 15.94 & 1.036 \\
D-Galactose & 16.16 & 1.050 \\
\hline
\end{tabular}


Table 3. Neutral sugar distribution (In weight percentages *) in model compounds.

\begin{tabular}{|c|c|c|c|c|c|c|}
\hline Compound & $\begin{array}{l}\text { Hydrolysis } \\
\text { procedure }\end{array}$ & Arabinose & Xylose & Mannose & Glucose & Galactose \\
\hline \multirow[t]{4}{*}{ Xylan } & \multirow{2}{*}{$\begin{array}{l}\text { Trifluoro- } \\
\text { acetic acid }\end{array}$} & 10.6 & 71.8 & not detected & 16.8 & 0.8 \\
\hline & & 11.0 & 71.4 & not detected & 17.1 & 0.6 \\
\hline & \multirow[t]{2}{*}{$\mathrm{H}_{2} \mathrm{SO}_{4}$} & 10.5 & 72.6 & not detected & 17.0 & trace \\
\hline & & 9.9 & 73.6 & not detected & 16.5 & trace \\
\hline \multirow[t]{4}{*}{ Cellulose } & \multirow{2}{*}{$\begin{array}{l}\text { Trifluoro- } \\
\text { acetic acid }\end{array}$} & not detected & 22.6 & not detected & 77.4 & not detected \\
\hline & & not detected & 23.2 & not detected & 76.8 & not detected \\
\hline & \multirow[t]{2}{*}{$\mathrm{H}_{2} \mathrm{SO}_{4}$} & not detected & 4.6 & 2.7 & 92.7 & not detected \\
\hline & & not detected & 4.3 & 2.6 & 93.2 & not detected \\
\hline
\end{tabular}

" weight percentage $-\frac{\text { weight of Individual sugar }}{\text { welght of total neutral sugars }} \times 100$

lulose. The two hydrolysis procedures appear to give very disparate xylose values. However, when the weight percent of xylose in the neutral sugar distribution is calculated on the basis of initial sample weight, an average xylose value of $4.6 \%$ was obtained for the trifluoroacetic acid procedure. This value is essentially equivalent to the average $4.4 \%$ xylose value determined by the $\mathrm{H}_{2} \mathrm{SO}_{4}$ method. This would seem to imply that the trifluoroacetic acid readily converts the hemicellulose to monosaccharides but reacts with the cellulose much more slowly. From the results obtained with the model compounds, it was thus evident that the sulfuric acid procedure was the best method for the hydrolysis of polysaccharides.

In the sulfuric acid procedure, the initial treatment with $12 \mathrm{M} \mathrm{H}_{2} \mathrm{SO}_{4}$ at room temperature for two hours cleaves the glycosidic bonds in the polysaccharide. The subsequent six-hour reflux with $0.36 \mathrm{M} \mathrm{H}_{2} \mathrm{SO}_{4}$ hydrolyzes the glycosyl sulfates produced in the first step (5). Because of the demonstrated greater applicability of this procedure, a shortening of reaction time for either of these two steps was deemed beneficial. A tobacco cell wall fraction was used to investigate the effect of altering these times. The results are summarized in Table 4.

Table 4. Tlme effects in $\mathrm{H}_{2} \mathrm{SO}_{4}$ procedure on Klason residue and neutral augar contents.

\begin{tabular}{c|c|c|c}
\hline \multicolumn{2}{c|}{ Time } & \multirow{2}{*}{$\begin{array}{c}\text { Klason } \\
\text { residue }(\%)\end{array}$} & $\begin{array}{c}\text { Total neutral } \\
\text { sugars }(\%)\end{array}$ \\
\hline $12 \mathrm{M} \mathrm{H}_{2} \mathrm{SO}_{4}$ & Reflux & & \\
\hline 2 & 21 & 11.8 & 54.1 \\
2 & 6 & 12.8 & 63.4 \\
2 & 4 & 14.6 & 55.4 \\
2 & 2 & 15.6 & 44.5 \\
1 & 6 & 17.1 & 55.8 \\
\hline
\end{tabular}

The results indicate that decreasing the total reaction time from eight to four hours reduces the amount of material hydrolyzed. It appears that if the time for the $72 \% \mathrm{H}_{2} \mathrm{SO}_{4}$ treatment is reduced, there is less polysaccharide conversion; whereas, if the reflux time is de- creased, the hydrolysis of the glycosyl sulfates is reduced. However, if the reflux time is greater than the standard six hours, there is a decrease in the total neutral sugar content of the hydrolyzate possibly due to degradation of the monosaccharides into non-sugar moieties. It thus appears that the standard conditions for the sulfuric acid hydrolysis represent a compromise between uniform hydrolysis of the polysaccharide fraction and degradation of the monosaccharide products.

As shown in Figure 1, the tobacco cell wall components were separated into two classes: a water-soluble fraction and an insoluble fraction. In order to obtain a more complete understanding of the effect of the intermediate extraction steps on the separation of the structural components, portions of the residue from the Termamyl treatment were either alkaline extracted or detergent extracted. The residues from the Termamyl treatment and the two intermediate extractions just described plus the insoluble and water-soluble fractions were analyzed for structural components. The results are summarized in Tables 5 and 6.

The Termamyl residue should be the first fraction to consist primarily of the structural biopolymers. The neutral sugar distribution clearly indicated that the residue from the Termamyl treatment did contain the structural polysaccharides - pectins, hemicelluloses and cellulose. Extraction with $\mathrm{KOH}$ or detergent removed pectin as indicated by the decrease in rhamnose, arabinose and galactose, the principal neutral sugars generally associated with galacturonic acid in pectin. The data also indicated that the detergent extraction more effectively solubilized pectin than did the alkaline extraction. The detergent extraction removed some hemicellulose as indicated by the decrease in xylose content of the residue.

The neutral sugar analysis showed the insoluble fraction contained xylose and mannose in addition to glucose. Although unexpected, the presence of these two aldoses was not surprising since xylose and mannose have been previously found in high purity cellulose. The absence of fucose in the neutral sugar distribution was thought to indicate that no xyloglucans were present (1). Thus it was assumed that all the glucose was de- 
Table 5. Neutral sugar analysis of tobacco cell wall fractions.

\begin{tabular}{l|c|c}
\hline Fraction & $\begin{array}{c}\text { Neutral sugars } \\
(\%)\end{array}$ & $\begin{array}{c}\text { Klason residue } \\
(\%)\end{array}$ \\
\hline I. Termamyl residue & 35.4 & 11.0 \\
II. Intermedlate extractions & & \\
a. Alkaline residue & 70.3 & 16.7 \\
b. Detergent residue & 70.9 & 17.0 \\
III. Insoluble fraction & 87.8 & 20.0 \\
IV. Water-soluble fraction & 22.3 & 5.5 \\
\hline
\end{tabular}

rived from cellulose and that the hemicelluloses associated with the cellulose consisted of xylans and mannans. It was speculated that these hemicelluloses were tightly bound to the surface of the cellulose. Alternately, it has been reported that lignin can interfere with the extraction of hemicellulose from cellulose (7). If the latter explanation is correct, then the xylose may represent a xylan similar to that found by $E d a$ et al. (8) in tobacco stalk holocellulose.

The water-soluble fraction was expected to contain pectin and soluble hemicellulose. This was confirmed by the neutral sugar distribution. Bokelman et al. (2) reported this fraction had a $22.5 \%$ uronic acid content. Bourne et al. (9). reported cured leaf pectin was composed of $\sim 90 \%$ galacturonic acid and $\sim 10 \%$ neutral sugars. More recent work by Eda and Kató (10) reported pectin isolated from tobacco midrib contained $83.7 \%$ galacturonic acid, $2.2 \%$ rhamnose, $2.4 \%$ arabinose, $11.2 \%$ galactose and small amounts of xylose and glucose. Based upon the earlier reference (9), it was calculated that of the $22.3 \%$ total neutral sugar content of the water-soluble fraction, $2.5 \%$ were assumed to be associated with pectin and the remaining $19.8 \%$ were thought to represent the soluble hemicellulose present in this fraction. It appears from the neutral sugar distribution that the soluble hemicellulose primarily consists of arabinogalactans and/or arabinorhamnogalactans. The low level of glucose and the trace amounts of xylose and mannose suggest that other soluble hemicelluloses may be minor constituents of this fraction. Eda and $K a t \bar{o}(11,12)$ have isolated 4-O-methylglucuronoxylan and arabinoxyloglucan from tobacco midrib. Mori and Katö (13) have found an arabinoglucuronomannan in suspension cultured tobacco cells.
Figure 4. Gas chromatogram of the alditol acetate derivatives of the neutral sugars present in the water-soluble tobacco cell wall fraction.

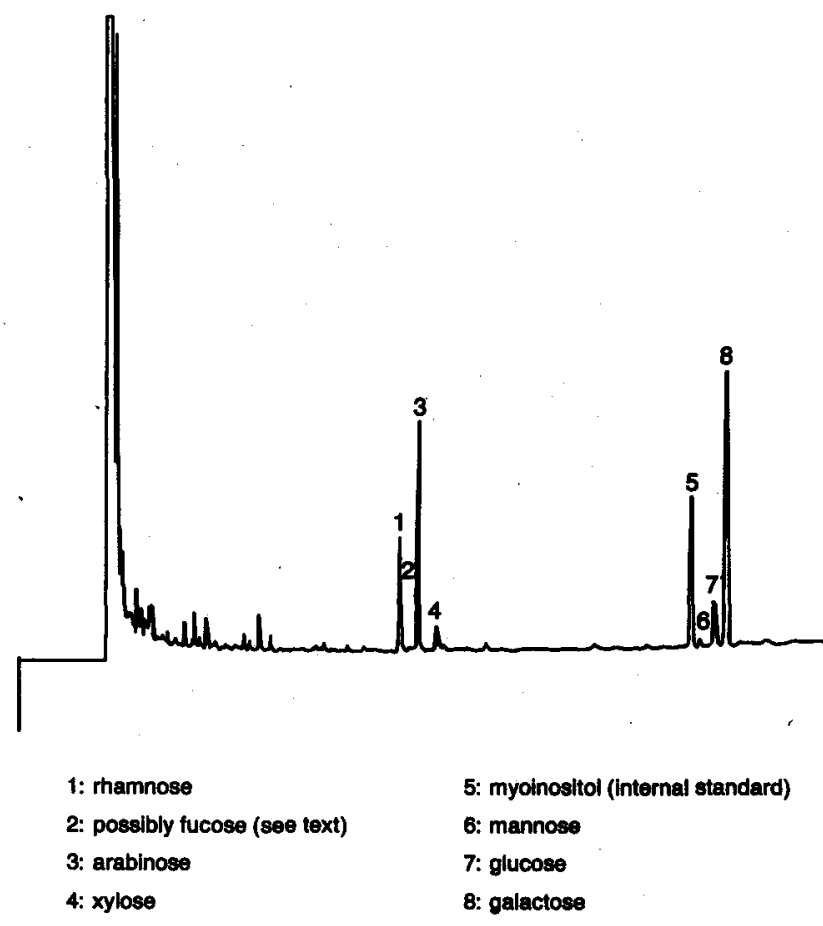

The gas chromatogram for the alditol acetates obtained from the neutral sugars present in the water-soluble fraction is shown in Figure 4. A small peak appearing at approximately the same retention time as the alditol acetate derivative of fucose is barely discernible. This cell wall fraction is the only one analyzed to date that may possibly contain fucose. However, the minuteness of the peak makes it impossible at this time to determine unequivocally if fucose is present in tobacco. If fucose were absent, it would indicate that no xyloglucans were present (1). If true, this finding with Bright lamina is consistent with previous tobacco tissue culture research that demonstrated that tobacco is the only known dicot which does not contain xyloglucans (14). Obviously, additional work is necessary to resolve this ambiguous presence of fucose.

Table 6. Neutral sugar distribution (in weight percentages) of tobacco cell wall fractions.

\begin{tabular}{|c|c|c|c|c|c|c|c|}
\hline & Rhamnose & Arabinose & Xylose & Mannose & Glucose & Galectose \\
\hline 1. & Termamyl residue & 4.8 & 9.6 & 10.0 & 4.4 & 57.8 & 13.3 \\
\hline II. & $\begin{array}{l}\text { Intermediate extractions } \\
\text { a. Alkaline Residue } \\
\text { b. Detergent Residue }\end{array}$ & $\begin{array}{l}\text { not detected } \\
\text { not detected }\end{array}$ & $\begin{array}{c}3.5 \\
\text { not detected }\end{array}$ & $\begin{array}{r}11.7 \\
7.2\end{array}$ & $\begin{array}{l}5.4 \\
4.8\end{array}$ & $\begin{array}{l}75.9 \\
87.4\end{array}$ & $\begin{array}{l}2.7 \\
0.7\end{array}$ \\
\hline III. & Insoluble fraction & not detected & not detected & 6.3 & 5.4 & 88.3 & not detected \\
\hline & Water-soluble fraction & 14.8 & 26.9 & trace & trace & 8.3 & 50.1 \\
\hline
\end{tabular}




\section{REFERENCES}

1. McNeil, N., A. G. Darvill and P. Albersheim: The structural polymers of the primary cell walls of dicots; Fortschr. Chem. Org. Naturst. 37 (1979) 191-249.

2. Bokelman, G. H., W. S. Ryan, Jr., and E. T. Oakley: Fractionation of Bright tobacco; J. Agric. Food Chem. 31 (1983) 897-901.

3. Theander, O., and P. Aman: Studies on dietary fibres, 1. Analysis and chemical characterization of water-soluble and water-insoluble dietary fibres; Swed. J. Agric. Res. 9 (1979) 97-106.

4. Albersheim, P., D. J. Nevins, P. D. English and A. Karr: A method for the analysis of sugars in plant cell-wall polysaccharides by gas-liquid chromatography; Carbohydr. Res. 5 (1967) 340-345.

5. Sarkanen, K. V., and C. H. Ludwig: Lignins - occurrence, formation, structure and reactions; Wiley-Interscience, New York, N. Y., 1971.

6. Oshima, R., A. Yoshikawa and J. Kumanotani: High resolution gas chromatographic separation of alditol acetates on fused-silica wall-coated open-tubular columns; J. Chromatogr. 213 (1981) 142-145.

7. Whistler, R. L., and E. L. Richards: Hemicelluloses; in: The Carbohydrates, Vol. IIA, edited by W. Pigman and D. Horton, Academic Press, New York and London, 1970, pp. 447-469.

8. Eda, S., A. Ohnishi and K. Katō: Xylan isolated from the stalk of Nicotiana tabacum; Agr. Biol. Chem. 40 (1976) 359-364.
9. Bourne, E. J., J. B. Pridham and H. G. J. Worth: Pectic substances in cured and uncured tobacco; Phytochemistry 6 (1967) 423-431.

10. Eda, S., and K. Katō: Pectin isolated from the midrib of leaves of Nicotiana tabacum; Agric. Biol. Chem. 44 (1980) 2793-2801.

11. Eda, S., F. Watanabe and K. Kato: 4-O-Methylglucuronoxylan isolated from the midrib of Nicotiana tabacum; Agric. Biol. Chem. 41 (1977) 429-434.

12. Eda, S., and $K$. Katō: An arabinoxyloglucan isolated from the midrib of the leaves of Nicotiana tabacum; Agric. Biol. Chem. 42 (1978) 351-357.

13. Mori, M., and $K$. Katō: An arabinoglucuronomannan from suspension-cultured cells of Nicotiana tabacum; Carbohydr. Res. 91 (1981) 49-58.

14. Bokelman, G. H.: Unpublished research, 1980.

\section{Acknovledgement}

The tecbnical assistance of W. F. Suiter is gratefully acknowledged.

Author's address:

Pbilip Morris Research Center,

P. O. Box 26583,

Richmond, Virginia, 23261, U. S. A. 